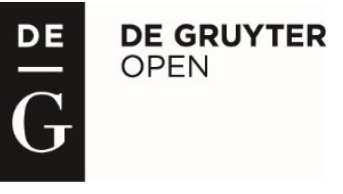

LEGE ARTIS

Language yesterday, today, tomorrow

Vol. III. No 12018

\title{
METAFICTION IN CONTEMPORARY ENGLISH-LANGUAGE PROSE: NARRATIVE AND STYLISTIC ASPECTS
}

\section{Olena Tykhomyrova}

\author{
Kyiv National Linguistic University, Kyiv, Ukraine
}

Tykhomyrova, O. (2018). Metafiction in contemporary English-language prose: Narrative and stylistic aspects. In Lege artis. Language yesterday, today, tomorrow. The journal of University of SS Cyril and Methodius in Trnava. Warsaw: De Gruyter Open, 2018, III (1), June 2018, p. 363-416. DOI: 10.2478/lart-2018-0010 ISSN 2453-8035

\begin{abstract}
This paper focuses on metafictional narrative strategies characteristic of contemporary English-language fiction. The research reveals the variety and stylistic peculiarities of these strategies, as well as specifies the definition of metafiction with regard to its liminal status and selfreflexivity. Narrative metalepsis, specific framing and plot arrangements, metafictional commentary, and other techniques have been analyzed resorting to numerous examples.
\end{abstract}

Key words: fantasy fiction, fictionality, genre, illusion, liminality, magic realism, metafiction, metalepsis, metaphor, narrative strategy, paradox, parody, plot, self-reflexivity.

\section{Introduction}

The term "metafiction" has posed problems for scholars ever since it was first coined in the essay "Philosophy and the future of fiction" by Gass (1980: 7). Its pitfalls can be exemplified by the classical definition of metafiction, offered by Waugh (2001: 2) several years later:

Metafiction is a term given to fictional writing which self-consciously and systematically draws attention to its status as an artefact in order to pose questions about the relationship between fiction and reality. In providing a critique of their own methods of construction, such writings not only examine the fundamental structures of narrative fiction, they also explore the possible fictionality of the world outside the literary fictional text.

The reference to "systematicality" in this definition is rather problematic since it limits 
the notion of metafiction to a number of radical postmodernist texts (such as "Lost in the funhouse" by John Barth), where the exposure of fictionality is indeed essential. Yet, the phenomenon of drawing attention to the text's artificiality has been ubiquitous in contemporary literature, although not necessarily systematic in a given novel, while numerous examples of it can be also found in $18^{\text {th }}$ and $19^{\text {th }}$ century literature, most notably in Laurence Sterne's "Tristram Shandy", "The granddaddy of all metafictional novels", as Lodge dubs it (1992: 206). Thus, the current tendency is to regard metafiction not as a (sub)genre, but a particular feature of fiction, which is manifested in its self-reflexivity (also referred to as self-reflexiveness, self-awareness, selfconsciousness, etc.). The problem has inspired a substantial number of research and theoretical analyses, the most prominent scholars writing on metafiction being Currie (1995; 2004), Fludernik (2009), Hanebeck (2017), Hutcheon (1980; 1988; 2000), Waugh (2001), Wolf (2005; 2013), and others. In terms of literary criticism, metafiction has been often viewed in close connection with postmodernism, postcolonial writing, and magical realism; there have also been works that applied a historical perspective to metafiction and regarded the phenomenon within the feminist paradigm (Ingersoll 2001; Peters 2002). Linguistic aspects of metafictional discourse have so far received comparatively little academic attention, and, although a few attempts at its narrative analysis have been made, the problem still remains undoubtedly topical. Stylistic dimensions of self-reflexivity in fiction provide a particularly bountiful field for research.

\section{Metafiction: A narrative approach}

Theoretical conceptualization of metafictional narratives necessarily addresses their ontological status, which has been viewed by various scholars as a certain "tension zone" between fiction and reality. Hutcheon emphasizes the correlation between fiction and contemporary uncertainty about reality, manifested in "a loss of faith in our ability to (unproblematically) know that reality, and therefore to be able to represent it in language" (1988: 119). The notion of narrativization of our experience rises in this context, and thus the study of metafiction turns into an exploration of certain liminality 
as it represents the interpenetration of fiction and reality. Currie verbalizes the same idea in terms of "the boundary between art and life", the realization of which he sees in such works as, for example, "The French lieutenant's woman" by John Fowles (Currie 1995: 4).

Another dimension of liminality that is particularly resonant for metafictional discourse can be found in the incorporation of criticism into fiction. The $20^{\text {th }}$ century saw an outstanding upheaval in theoretical appreciation of literature, and as a result the literature itself became involved in its own interpretation. As Currie states in his interdisciplinary study "Difference", the current effect of this process on fiction is that it "assimilates and incorporates critical and theoretical perspectives into its discourse as self-knowledge" (Currie 2004: 110). It can be observed in the novels whose authors are both literary critics and writers, such as David Lodge and Antonia Byatt.

Approaching metafiction from a narrative perspective requires a more precise definition of this phenomenon. Since we have seen that it is neither a genre of literature nor a type of a novel, there is a need to state what it encompasses. After arriving at such a definition, a further exploration of metafictional strategies will become viable. The aim of this paper is to elucidate the liminal status of metafiction and uncover its stylistic potential with a particular emphasis on the effects it elicits in various contexts. The material of the research comprises contemporary English-language prosaic texts ranging from famous novels, often cited in this respect (such as "The French lieutenant's woman") to works less favoured by scholars, including examples from fantasy fiction. The aim of the paper and the chosen subject matter predetermine the necessity to resort to such methods as narratological analysis, including the point of view analysis and building upon Genette's structural approach to narrative levels. The study of metafictional effects will rely on linguo-stylistic and contextual analyses, resorting to a cognitive approach when metaphoric image-creating is considered. 


\subsection{Defining metafiction}

Leaving aside all popular labels that attempt to position metafiction thematically, e.g., "fictions about fiction" (Gass 1980: 7) or vaguely hint at its liminal status, I will mainly rely on the definition given by Fludernik (2009: 156): "A narrative strategy or a comment on the part of the narrator is metafictional if it explicitly or implicitly draws attention to the fictionality (fictitiousness or arbitrariness) of the story and the narrative discourse".

Another helpful definition is provided by Williams, who resists the usage of the term "metafiction", objecting to the semantic loading of "superiority" imposed by it (Williams 2004: 8). In his profound "Theory and the novel: Narrative reflexivity in the British tradition" Williams sticks to the term "narrative reflexivity", emphasizing the complex nature of linguistic representation in a narrative (ibid., 71). Although Williams' research abounds in useful insights that are going to be applied here, the traditional usage of the term "metafiction" has already become universally accepted and therefore has to be preserved. Thus, metafiction will be regarded in this paper as a narrative strategy that highlights the fictionality of the text by employing reflexive techniques. Systematic usage of such strategies in a given text may confer a metafictional status onto the whole work, yet it is important to point out that metafiction is regarded here as a device, and as such it can be singled out and analyzed in any kind of fictional text, whether it is used there systematically or episodically.

\subsection{Illusion-breaking}

Metafictional exposure of fictionality is connected with the notion of aesthetic illusion, one of many visual metaphors characteristic of narrative analysis. The thesis about metaficton that is commonly maintained dictates the necessity for the illusion of reality created by the text to be broken. Ruminations about illusion-breaking in literature date back to the $19^{\text {th }}$ century and Samuel Taylor Coleridge's famous theory about "willing suspension of disbelief", which later featured extensively in discussions concerning the nature of readers' belief in fictional reality (see Abrams \& Harpham 2012: 129). In his 
outline of theoretical issues concerning aesthetic illusion, Wolf views it as a transmedial phenomenon and defines it as "a particular imaginative response to representational artefacts" (2013: 6). He concludes that aesthetic illusion is an ambivalent effect, since it combines immersion and distance, turning the study of its breaking into a "natural complement" to the research of the phenomenon itself (ibid., 55). The exact manner of undermining this illusion in fictional texts, liminal tension of the process, and its stylistic impact are of particular interest for the present study, since these are the main factors that shape the responses elicited by metafictional strategies.

Several attempts have been made to define metafictional illusion-breaking. Waugh (2001: 14) speaks of "frame and frame-break, of technique and countertechnique, of construction and deconstruction of illusion" as indispensable elements in all fiction but exaggerated and highlighted in metafiction. Fludernik specifies the notion as "the illusion of a fictional world" and argues that metafictional strategies do not necessarily shatter it; on the contrary, they might intensify this illusion in certain circumstances (Fludernik 2009: 63). Similar to this, Williams (2004: 90) also perceives more complex processes in the operation of self-reflexivity, reaching far "beyond the simple exposure of the "illusion of fiction". Taking up Fludernik's concern regarding the impression of authenticity (2009: 55), I will focus on stylistic effects produced by various forms of metafictional frame-breaking, determining whether the illusion of reality is indeed broken, or, on the contrary, paradoxically authenticated, resulting in the sense of immersion into the fictional world. Other possible effects of frame-breaking, particularly humorous, will also be considered.

\section{Narrative metalepsis}

One of the most explicit ways of illusion-breaking is often referred to as narrative metalepsis, a term coined by Genette in his influential work on narratology "Narrative discourse" (1983: 235-236). Genette defines metalepsis as a transgression between narrative levels (namely between diegetic and extradiegetic levels). To add some precision to this issue, Fludernik's differentiation of these levels can be applied: she 
refers to them as "the level of the world represented in the story and the level at which this representation takes place. In the novel, the latter level is that of the narrative discourse (level of narrative mediation)" (Fludernik 2009: 21). The former corresponds to Genette's (intra)diegetic level and encompasses characters and the fictional world, while the latter is analogous to the extradiegetic level comprising narrators and narratees, who are perceived to be outside the story. Thus, transgressions between these two levels occur when narrators (particularly those that assume an "authorial voice") or narratees unexpectedly enter into communication with characters or simply enter the fictional world, from which they seemed to be excluded (or vice versa). Ryan views metalepsis as a manifestation of ontological impossibility, calling it "a device which exploits the recursive character of fictionality" (2013: 135). Logical impossibility predetermines the illusion-breaking effect of metalepsis, since narrative levels (the level of the representation and the represented) are often perceived as different domains separated by a boundary. It is this boundary that is violated or broken down, as it is famously metaphorized in theatrical discourse with the concept of the "fourth wall". In an attempt to move away from the definition that relies on the metaphor of boundary, Hanebeck lays the emphasis on representational logic (2017: 77):

Metalepsis occurs when and if a recipient of a (narrative) representation feels that the logic of acts of (narrative) representation is violated or negated in such a way that the 'natural' spatial, temporal and hierarchical relationships between the domain(s) of the signifier and the domain(s) of the signified no longer apply.

In this paper narrative metalepsis in fictional texts is viewed as any transgression between the levels of the representation and the represented that defies the assumed logic of the correlation between the corresponding domains (or fictional worlds). The degree to which this violation is perceived as "impossible" or unexpected defines the effect it produces in a specific context.

\subsection{Degrees of metalepsis}

Several scholars (Fludernik, Hanebeck, Klimek, Nelles, Ryan) offered their typologies of narrative metalepses, often drawing the border line between "unmarked" and 
"marked" cases and defining the two distinct types as figurative / rhetorical and ontological ${ }^{1}$, which Ryan described respectively as "a temporary window between levels" and a violation of logical distinction between levels (2006: xxiii). In a detailed account of metaleptic types, Hanebeck (2017: 81-107) further elaborates the marked (ontological) case, dividing it into "recursive" and "immersive" metalepses, both of which also comprise several subtypes. Immersive metalepsis is viewed by Hanebeck as the most disruptive ontological type: a transgression of narrative levels in "a negation of the logic of the act of narrative representation" (ibid., 94). Since the notion of "immersion" has been often associated with aesthetic illusion (see, for example, Wolf 2013: 11-19), Hanebeck has to specify that he applies the term differently, namely, "to express the fact that ontological metalepses literally place narrative entities in a diegetic universe to which they do not 'belong."' (2017: 94). To avoid confusion, it seems reasonable not to mix metaphors and preserve the notion of immersion for the discussion of metaleptic effects, which will be done later in this paper. The matter of metaleptic disruptiveness itself, on the other hand, needs some revision, since even a conspicuous case of a penetration into a different narrative level does not necessarily lead to radical illusion-breaking. Wolf states that aesthetic illusion is both gradable and unstable in its nature (2013: 23), and I argue that the same can be applied to metafictional strategies in general (since they aim at destabilizing this illusion) and to metalepsis in particular.

The definition of metalepsis given above offers two axes for grading the phenomenon: its perceived "impossibility" and unexpectedness. The former relies on the correlation between the extradiegetic / diegetic / hypodiegetic levels and the fictional domains they correspond to. The further they are apart ontologically (in terms of their general credibility, as well as their spaciotemporal parameters), the more impossible interpenetration might appear, unless there is a fictional premise for its possibility. Thus, Woody Allen's short story "Kugelmass episode", given by Hanebeck as an example of ontological metalepsis, can be read differently due to its fantastical premise: a magician wielding a special machine sends the protagonist into the fictional world of 
"Madame Bovary". If the premise itself does not shatter the aesthetic illusion for the reader, the metaleptic movement of the protagonist will not be perceived as totally impossible either. Thus, the degree of disruptiveness will remain comparatively low. On the other hand, it is reinforced almost immediately after the protagonist's penetration into the hypodiegesis in the following manner: "Emma turned in surprise. "Goodness, you startled me," she said. "Who are you?" She spoke in the same fine English translation as the paperback" (W. Allen "Side effects", p. 66). The language itself underpins the fictionality of Emma's existence and its dependence on the printed book, driving the two worlds further apart and increasing the general disruptive effect.

In grading metalepsis on the basis of its suddenness in narration, I treat the notion of unexpectedness in terms of deviation as a means of linguistic foregrounding, occurring on several levels (see Gregoriou 2014: 90-94). It is most obvious at the level of the plot, since the reader may be prepared for a metaleptic transgression, as in "Kugelmass episode", where a visit to a magician forestalls the surprise, or it may happen without warning. At the level of narration, metalepsis may be signaled by shifts in focalization / point of view, as it is seen in the same story later: "His heart danced on point. I am in love, he thought, I am the possessor of a wonderful secret. What he didn't realize was that at this very moment students in various classrooms across the country were saying to their teachers, "Who is this character on page 100? A bald Jew is kissing Madame Bovary?" A teacher in Sioux Falls, South Dakota, sighed and thought, Jesus, these kids, with their pot and acid. What goes through their minds!" (W. Allen "Side effects", p. 67-68). What earlier appeared as a limited third-person narration with Kugelmass as a point of view character, suddenly shifts to a third-person omniscient, starting from "What he didn't realize was that", and further diverts from the expected course by a glimpse into an unnamed teacher's mind. Ontologically, this episode also destabilizes the correlation between the fictional worlds by suggesting a previously unsuspected impact of the protagonist's intrusion into the hypodiegetic "Madame Bovary" on the novel itself in the diegetic universe. 


\subsection{Stylistic aspects of metalepsis}

In describing narrative metalepsis, Genette stated that it produced an effect of strangeness that is either comical or fantastic (1983: 235). Both are attributable to the paradoxical or incongruous nature of the phenomenon itself and the underlying psychological mechanisms, and can, therefore, be explained in terms of the humour theories based on the category of incongruity. Such explanation, however, is beyond the scope of this paper, which aim is to pinpoint stylistic effects associated with metaleptic transgression in fiction. As it has been shown above, these effects depend on the degree to which a specific transgression disrupts the corresponding aesthetic illusion.

General paradoxality of metaleptic transgression accounts for ambiguity and potential complexity of interpretation. A highly disruptive metalepsis may be perceived as subversive and perplexing or, on the other hand, engaging and challenging. Commenting on the latter and elaborating on Wolf's idea of "activating the recipient" by means of metalepsis, Hanebeck (2017: 112-113) introduces the term "hermeneutic effect" to emphasize both the multitude of possible meanings and difficulty of their systematizing:

Metalepsis not only offers the paradoxical impossibility of denying its own prerequisites, but also denies the very spatiotemporal make-up of our understanding, of how we make sense of the world. It is this denial that destabilizes readings, proliferates meanings, and prolongs the dynamic instigated by such transgressions. Thus, the device's hermeneutic effect, which lays bare the concepts that make metalepsis possible in the first place, can be conceptualized as the gnomonic shadow haunting all attempts to make sense of metalepsis.

But once the reader accepts the premise under which the transgression is made and / or the challenge that its interpretation presupposes, a humorous effect will be the typical outcome, each specific occurrence creating its unique slant channeled through the interaction with the plot and stylistic environment in which metalepsis is realized. The dominant humorous effect is that of irony, which relies, ontologically, on the inherent incongruity of a metaleptic situation, and linguistically, on the collocative clash, that is, "a combination of words which conflicts with our expectations" (Leech \& Short, 
2007: 223). Both can be illustrated by examples from Allen's "Kugelmass episode". The protagonist's intrusion into Flaubert's novel is rendered ironic by a comment from a literary scholar, in which a truism about always finding something new in old texts becomes a contextual reality: "I cannot get my mind around this, " a Stanford professor said. "First a strange character named Kugelmass, and now she's gone from the book. Well, I guess the mark of a classic is that you can reread it a thousand times and always find something new" (W. Allen "Side effects", p. 72). Linguistically, Emma's diction, unexpectedly modern and rich in slang, contributes to the humorous effect of metalepsis due to the collocative clash: "I've never been so happy!" Emma squealed as she stood before the mirror. "Let's go out on the town. I want to see Chorus Line and the Guggenheim and this Jack Nicholson character you always talk about. Are any of his flicks showing?" (ibid.).

A variability of the degree of disruptiveness and the ambiguous nature of metalespis can be traced in a well-known example from "The French lieutenant's woman", a postmodern historical novel by John Fowles set in Victorian England. In one of the episodes the protagonist (Charles) boards the train and faces a man who turns out to be the narrator. At first, the focalization is external and the man is described as "an intent watcher" staring at Charles, but then he merges with the "I" of the narrator: "It is precisely, it has always seemed to me, the look an omnipotent god - if there were such an absurd thing - should be shown to have. Not at all what we think of as a divine look; but one of a distinctly mean and dubious (as the theoreticians of the nouveau roman have pointed out) moral quality. I see this with particular clarity on the face, only too familiar to me, of the bearded man who stares at Charles. And I will keep up the pretense no longer.

Now the question I am asking, as I stare at Charles, is not quite the same as the two above. But rather, what the devil am I going to do with you?" (J. Fowles "The French lieutenant's woman", p. 317)

The effect of this narrative metamorphosis, introduced by the repetition (man who 
stares at Charles - as I stare at Charles), is not totally disruptive in terms of it suddenness. It is not fully unexpected since it is partially forestalled by the metanarrative commentary that permeates through the novel. In this particular excerpt reference is made to "the theoreticians of the nouveau roman", while the look on the face of "the intent watcher" is compared to that of an omnipotent god, the literary equivalent of an "omniscient narrator", ridiculed in the episode. Metanarrative commentary as a metafictional strategy will be discussed later, but here it is worth mentioning that its complex syntax, abundance of parenthetical constructions, and deliberate mixture of different stylistic registers create a specific environment for the metalepsis, in which it does not feel like a radical transgression. It does, however, undermine the aesthetic illusion one might expect from a historical novel by a violation of the diegesis (belonging to Victorian England) by means of the entry of a contemporary agent. This subversive moment prepares the ground for the alternative endings of the novel through a question that turns the protagonist into a second-person entity (what the devil am I going to do with you?). These elements of the novel have often delighted both critics and readers, although the latter could also be perplexed, feeling that their expectations of enjoying a stylized Victorian novel were somehow deceived.

\subsection{Metalepsis in fantasy fiction}

The necessity to treat metaleptic transgressions in fantasy fiction as a separate case is predetermined by the specificity of the genre itself and its dependence on storyworlds where magic is possible. In her study of metareference in fantasy fiction ${ }^{2}$, Klimek pointed out (2011a: 79) that metafictional strategies seem to be incompatible with the genre's premises:

The subgenre of fantasy fiction which has thus been defined is not usually associated with metareference. Indeed, the very idea of metareferential fantasy fiction seems to be a contradiction within itself, as metareference would be expected to tendentially break the coherence of the plot in the magical Otherworld and have a negative influence on the inner logic of enchantment and wonder that rules the story world.

It is particularly resonant for narrative metalepsis, which status relies on the perceived 
impossibility of a certain transgression and which effects exploit the paradoxality of aesthetic illusion and its breaking. Yet the magical premise of a fantasy storyworld may render metalepsis possible and thus not paradoxical. The question arises whether it is terminologically correct to speak of metalepsis when its mechanism is consistent with the inner logic of the secondary world. In a different paper, focused entirely on metalepsis in fantasy fiction, Klimek reiterates that paradoxality is prerequisite for the phenomenon's occurrence: "The hierarchical levels of representation and of what is being represented must be mixed up in a paradoxical way" (2011b: 24). The instance that she gives, however, e.g., Cornelia Funke's "Tintenwelt" trilogy, does not support this claim, since the main magical premise of the storyworld is the ability of the "silvertongue" protagonists (Mo and his daughter Meggie) to read characters out of books making them real in the diegetic universe. Thus, each case of a hypodiegetic character moving to a diegetic level is not paradoxical since it complies with the inner logic of the storyworld. Similarly, the storyworld in Jasper Fforde's "Thursday Next" series extensively relies on characters' ability to physically get into novels, turning into their personages and implementing changes in them.

This terminological conundrum can be solved by reserving the issue of paradoxality for the discussion of metaleptic effects and removing it from the narratological prerequisites of the phenomenon. The direction these effects may take in fantasy fiction depends precisely on how (un)paradoxical the transgression is according to the assumed logic of the correlation between extradiegetic / diegetic / hypodiegetic domains. I maintain that in terms of aesthetic illusion and its breaking, the effect may incline towards subversive irony on the one hand, and authentication of the secondary world on the other. In terms of emotional response, metaleptic transgressions may produce, as in any other genre, a humorous effect, but due to the specificity of magical premises it can also elicit negative reactions, including disorientation and fear, resulting in a disturbing overall effect. Since humorous effects, especially ironic, are typical for metalepsis in general, I will not provide examples from fantasy fiction, focusing instead on the phenomena of the authentication of a secondary world, as well 
as disturbing metaleptic effects.

\subsubsection{Metalepsis as an authenticating strategy}

In her study of metareference in fantasy Klimek resorted to the genre-defining classics by J.R.R. Tolkien and C.S. Lewis and quoted several instances of characters thinking of themselves as characters in a story (2011a: 80-84). She also mentioned the narrative roles assumed by the same authors (editor / storyteller), referring to this framing as a "traditional strategy of authentication" (ibid., 82). Although these instances are not metaleptic, they can be treated as precursors of later experiments with authenticating framing, aimed at bridging fictional worlds and the one perceived as "real". The role of mediator in this process may be assigned to a version of metalepsis configured by the rearrangement of narrative roles. In contemporary fantasy fiction, which has a noticeable tendency for encompassing postmodernist gambits, the phenomenon of narrative games can be observed in so called companion books, which provide additional dimensions within a fantasy storyworld, often employing intermediality. Such texts exploit the liminal tension of metafiction for their own purposes: the diegetic level in them corresponds to the storyworld, distinct from the "real world", while the extradiegetic level is identified with recognizable "reality". The narrative roles can be distributed between these levels in various combinations.

A luscious example of such combination is "Nanny Ogg's cookbook" written by Terry Pratchett, Stephen Briggs, and Tina Hannan, but attributed to the fictitious author Nanny Ogg, one of the chief characters in Terry Pratchett's Discworld series. The diegetic level here falls into sublevels: that of the fictitious author, whose projection is the I-narrator with a distinct colloquial style, and the level of the printer and the publisher, whose paratextual intrusions foreground the process of book-creation, which is typically concealed from the reader. Terry Pratchett and Stephen Briggs, on the other hand, enter the diegetic level as "editors" of the book and its adaptors for "our world". The mediating metaleptic effect here depends on their editorial and adapting functions: in "A note from editors" Pratchett and Briggs assume both that Discworld recipes are 
authentic and that real world readers will use them: "In many of the recipes we have had to tinker with ingredients to allow for the fact that the Discworld equivalents are unavailable, inedible, or worse. Few authors can make a long-term living out of poisoning their readers, at least physically" (S. Briggs \& T. Pratchett "Nanny Ogg's cookbook", p. 18). The peculiar effect of this mediation is not only humorous, but veritably authenticating since, rather than shatter the illusion of reality, they create another Discworld story that correlates with the already existing stories on the intertextual level and links it to both readers and authors in "our world" (for a more detailed account see Тихомирова 2011).

A similar authentication effect is achieved by J.K. Rowling in her "The tales of Beedle the Bard", a book of fairy tales attributed to the fictitious author, the $15^{\text {th }}$ century wizard Beedle the Bard. The book was mentioned in the last novel of the Harry Potter series, "Harry Potter and the Deathly Hallows", which had one of its tales embedded as a story-in-a-story. The extradiegetic level in "The tales of Beedle the Bard" is a frame comprising Rowling's "Introduction", in which she assumes the role of an adaptor of the tales for Muggle (non-magic) children. She also appears as the author of the footnotes to the text (marked with her initials), some of which become a vehicle for metalepsis: "Professor McGonagall, Headmistress of Hogwarts, has asked me to make clear that she became an Animagus merely as a result of her extensive researches into all fields of Transfiguration, and that she has never used the ability to turn into a tabby cat for any surreptitious purpose, setting aside legitimate business in behalf of the Order of the Phoenix, where secrecy and concealment were imperative. JKR" (J.K. Rowling "The tales of Beedle the Bard", p. 80).

Here Rowling in her editorial role is shown to be in contact with Minerva McGonagall, one of major characters in the Harry Potter series. The dry formal style of Rowling's footnotes correlates with the academic (and yet slightly ironic) slant of the commentary attributed to Albus Dumbledore, another significant character in the series. Dumledore's commentary and additional footnotes, as well as Rowling's introduction 
and footnotes, function as a foil to the tales, whose narrative perspective is typical of classical children's stories. Another narrative role is given to Hermione Granger, who "translated" the tales from the original runes. Both she and Harry Potter function as the readers of the tales in "Harry Potter and the Deathly Hallows", in which they and the fictitious author, Beedle the Bard, belong to the same fictional world. Thus, the book, just as "Nanny Ogg's cookbook", relies heavily on the corresponding fantasy series, develops the plots and characters already existing there, and contributes to the authenticity of the storyworld. Such texts foreground the "topos of narrative composition", to use Williams' term (2004: 25), and highlight the book-creation process, making metalepsis look almost natural in this environment. When employed for modeling a children's book within the storyworld, on the other hand, such narrative games tend to foreground the act of reading itself. The focus shifts to the interaction between children and adults, who read aloud for them, as in Pratchett's picture book "Where's my cow?", where a father, reading a book for his son, metaleptically substitutes the eponymous cow, usurping its place in the diegesis (see Тихомирова 2014). In this instance the authenticating and ironic aspects of the metalepsis overlap and interact to elicit a complex effect and celebrate the power of the act of reading.

\subsubsection{Disturbing effects of metalepsis}

It is the power of word and reading that also accounts for less gratifying effects of metalepsis in fantasy fiction. The magical ability to turn inanimate objects into living beings has been part of myths, legends, and fairy-stories since time immemorial. The Greek myth of Pygmalion and Galatea is perhaps the oldest known example of a work of art made real. As it is to be expected, fantasy fiction has often exploited the pattern, endowing characters with magical abilities to bring works of art to life, including separate objects / characters / places and entire fictional worlds. Such entities are sometimes ekphrastic, as sapient portraits of Hogwarts castle in the Harry Potter series or the Tooth fairy's domain in Pratchett's "Hogfather". Instances, relevant to the present paper, deal with the magical power to bring entities out of books, as in the above mentioned Funke's trilogy about "silvertongues". In the first book of the trilogy the 
protagonist is coerced to summon a monster from a novel, which is a case in point. Klimek refers to this text to illustrate the "frightening potential of ascending 3 metalepses" (2011b: 33). Calling a potentially dangerous creature into being out of a story is an evident example, the effect of which is undermined by the reader's certainty that heroes will defeat the monsters in the end. Yet, a disturbing and destabilizing effect can be achieved by the metaleptic potential for disorientation, when the nature of the transgression is not immediately evident.

Such a situation is created in Pratchett's "Wee free men", the first novel in the Tiffany Aching fantasy series for young adults. The protagonist of the story is a young witchin-the-making, Tiffany, who has to face a formidable enemy, the Faery Queen. The Queen's magic power enables her to create realistic illusions, into which she immerses her opponents. Tiffany's quest, therefore, lies in learning how to discern and fight illusions. Naturally, before she manages to achieve this, she is baffled and disoriented: "They were daisies. She knew it. She'd stared at them dozens of times, in that strange picture in the Faerie Tales. They were daisies, and these weren't giant reeds around her, they were blades of grass and she was very, very small.

She was in the weird picture. The picture was the dream, or the dream was the picture. Which way around didn't matter, because she was right in the middle of it. If you fell off a cliff, it wouldn't matter if the ground was rushing up or you were rushing down. You were in trouble either way" (T. Pratchett "Wee free men", p. 165). This is a case of ekphrastic metalepsis, which, nevertheless, does not undermine the fact that the protagonist feels trapped in a book. At the moment she has not yet figured out that it is an illusion since its sensory perception is vivid. The feeling of anxiety is underpinned with repetitions and antitheses: the recursive nature of the depiction creates a dreamlike effect bordering on a nightmare. The topos of a book (or another entity) brought to life and turned into a scary trap / opponent for the protagonist is a typical case of the disturbing metaleptic effect, which conveys the feelings of dismay, confusion, and fear of something that threatens the habitual picture of the world. As with Tiffany in "Wee free men" and other novels in the series, the protagonist's quest boils down to gaining 
mental clarity and recognizing illusions and deception (including their own flaws of thinking). In spite of the common association of fantasy fiction with the irrational, such quests reflect a contemporary awareness of our cognitive limitations and an urge to achieve a more mindful state through rationality and self-reflexivity.

\section{Plots and structures}

If we approach metafictional narratives from the perspective of the plot, it becomes clear that much more implicit strategies than metalepsis can be implemented to challenge the conventions of literature and highlight its fictionality. Practically every deviation from a classical linear arrangement of the storyline has a metafictional potential (which may or may not be realized in a particular text): a complicated structuring and deliberate fragmentation, an overemphasis on events or an overuse of coincidence, peculiar time shifts (both analeptic and proleptic), embedded stories, and other devices that might undermine the reader's "suspension of disbelief". These are often intertwined within a particular work of fiction, but for the purpose of this paper most typical cases are grouped in several sections below and analyzed in terms of their characteristic stylistic effects.

\subsection{Framing and fragmentation}

Since metafictional strategies rely on undermining aesthetic illusion, described as the specific mental state in which we seem to experience representations as if in real life (Wolf 2013: 11), those plot arrangements that are perceived as "unnatural" or artificial suggest a metafictional potential. Various plot arrangements of this kind can be found in the novels of Margaret Atwood, which have often been viewed by scholars in conjunction with the author's feminist sympathies. Commenting on the "patchwork" metaphor that describes the structural fragmentation of "Alias Grace", Ingersoll emphasizes (2001: 385) the deliberate artificiality of such arrangement: "The novel offers "patches" of "found" texts stitched together in a manner which foregrounds both their provenance as received texts and the constructedness of the larger text(ure) into which they have been worked". The term offered by Ingersoll to refer to this 
phenomenon is "engendered metafiction" since it deconstructs "the male narrative paradigm, in favor of unlimited alternatives" (ibid., 399). Another Atwood novel, "The blind assassin", modifies the concept of the self-begetting plot through an intricate pattern of frames. Tension is created between the two main characters shaping the narrative: sisters Laura and Iris, the former being the presumed author of the embedded novel (also called "The blind assassin") and the latter being the narrator and, as revealed in the end, the actual author of the embedded novel. The web of assumptions imposed on the reader from the beginning only to be broken later is constructed by several layers of narrative, clippings from newspapers and magazines, as well as ekphrastic descriptions of the three versions of the same photograph, out of each either Laura or Iris is cut out. The multi-facet metaphor "left-handed book", which the Iris-narrator uses, can be applied to the novel's metafictionality itself: "Laura was my left hand, and I was hers. We wrote the book together. It's a left-handed book. That's why one of us is always out of sight, whichever way you look at it" (M. Atwood "The blind assassin", p. 513).

The narratee that elderly Iris is addressing is her own granddaughter Sabrina from who she is separated, which renders a confessional tone to the narrative. At the same time, there is a challenge as well as confession. Iris's appeal to Sabrina concerning the girl's ancestry contains the sentiment that the revelations can be a shock as well as a relief, backed up by the urge to "reinvent yourself": "When I began this account of Laura's life - of my own life - I had no idea why I was writing it, or who I expected might read it once I'd done. But it's clear to me now. I was writing it for you, dearest Sabrina, because you're the one - the only one - who needs it now. Since Laura is no longer who you thought she was, you're no longer who you think you are, either. That can be a shock, but it can also be a relief. For instance, you're no relation at all to Winifred, and none to Richard. There's not a speck of Griffen in you at all: your hands are clean on that score. Your real grandfather was Alex Thomas, and as to who his own father was, well, the sky's the limit. Rich man, poor man, beggar-man, saint, a score of countries of origin, a dozen cancelled maps, a hundred levelled villages - take your 
pick. Your legacy from him is the realm of infinite speculation. You're free to reinvent yourself at will" (ibid.).

Once again, this appeal can be transferred to the novel itself, which is to be "reinvented" in the light of all ultimate revelations made in it. The interpretation of its sophisticated narrative also lies in the "realm of infinite speculation", though one of its more palpable suggestions is that narratives shape our identity, and the reality of a person is to a large extent a web of fictions, structured at will. Thus, the artificiality of the plot arrangement has an ideological side, which is aimed at emphasizing the significance of the notion of narrativization as a means of making sense of the world and oneself. The freedom of choice in the search for self-identity (take your pick; You're free to reinvent yourself at will) is also the freedom to choose one's own pattern to structure the perception of reality. The overall effect may still be quite ambivalent: liberating and celebrating selfreflective creativity on the one hand, and demotivating on the other, since the truth or even multiple truths about oneself can hardly be found in the intricate webs of fictions.

Another example of a novel with a similar effect, partially created by a complicated narrative structure (several layers of narrative, embedded stories, interaction of poetry and prose, inclusion of diaries, letters, and academic writing, etc.), aimed at the issue of identity-shaping narratives, is "Possession" by Antonia Byatt. The protagonists' quest for identity is metaphorized as being "inside the plot" and driven by it. One of the novel's narrative layers is the correspondence between two fictional Victorian poets, Randolph Henry Ash and Christabel LaMotte. These letters, also being the object of the $20^{\text {th }}$ century scholars' interest, capture the poets' romantic story. The notion of free will (or its absence, while in a plot) is voiced by Ash: "And the plot which holds us, the conventions which bind us, declare that I must, as a gentleman, acquiesce in that requirement, at least for a time, and hope that Fate, or the plotter who watches over our steps will decree some further meeting, some accidental re-opening..." (A. Byatt "Possession" p. 211). Since this sentiment also mirrors the one experienced by the $20^{\text {th }}$ century protagonist, it will be viewed in more detail below, in the "mise en 
abyme" section of the paper.

\subsection{Self-begetting novel}

One of more radical metafictional plot-oriented techniques is the text dealing with the production of itself, a "self-begetting novel" (a term coined by Kellman (1980)), also referred to as a "strange loop", an "endless loop", "tangled hierarchy", or a "Möbius strip" (see McHale 1987: 120-122). A typical self-begetting novel would be a story of an author gradually coming to write the text we are reading. In some cases it can be regarded as a subgenre of the "bildungsroman" (coming-of-age novel) known as the "künstlerroman" ("artist novel"). Waugh argues (2001: 14) that in such novels "the emphasis is on the development of the narrator, on the modernist concern of consciousness rather than the postmodernist one of fictionality", giving André Gide's "The counterfeiters" as an example. Still, recent decades have seen the publication of many novels in which the self-begetting twist of the plot can be affiliated with metafiction. Some scholars (Hanebeck 2017; Klimek 2011b) consider a Möbius strip story as one with a metaleptic potential, although Hanebeck points out that is only realized with a literal recursion or at least its suggestion (2017: 102). Since it is not always the case, I regard this type of plot separately.

One of the most outstanding examples of self-begetting novels is Ian McEwan's "Atonement", in which the protagonist seeks atonement for the mistake she has committed, which leads her to the conception, writing, and rewriting of the novel by the same name. While it still can be regarded as the künstlerroman, since it traces young Briony's transformation into a successful novelist, the text acquires a metafictional status due to the tension it generates between various narrative frames employed by the author. It ultimately addresses the issue of fiction and reality interconnection, reinforced by the construction of illusion and its repeated breaking (Tykhomyrova 2011a). The "loop" concept of the plot has been experimented with in cinematography: Sally Potter's "The tango lesson" and Spike Jonze's "Adaptation" focus on stories of screenwriters suffering from writer's block and finally ending up creating the scripts of 
corresponding films. Mahler views the topos of writer's block, manifestations of which in different media he scrutinizes in terms of the metareferential turn and the process of meatization, as one of the signs of the increasing awareness and interest in selfreflexivity in postmodern society (2011: 59). The liminal tension of this topos is foregrounded with the help of exploiting the "gap between metaization as a mere lack of inspiration, and metaization as a highly imaginative part of it" (ibid., 71).

The "negative" version of the self-begetting plot (when the result of writing a novel is not successful) has also been attempted: Joanne Harris' "The blackberry wine" features an author (also suffering from major writer's block) who seemingly finds inspiration in fresh surroundings and starts working on a new novel, which the reader expects to be the same as s/he is reading. Yet, as a result of a personal epiphany, the writer destroys the only copy of the novel before it could be published and denounces writing fiction. The metafictional plot-strategy is reinforced by the narrative discourse of the novel: it is a bottle of blackberry wine who narrates the story, implicitly enhancing the text's fictionality and creating a unique tonality: "This is where my story ends. Here, in the kitchen of the little farmhouse in Lansquenet. Here he pours me, releasing the scents of summers forgotten and places long past. He drinks to Joe and Pog Hill Lane; the toast is both a salute and a goodbye. Say what you will, there's nothing to beat the flavour of good grape. Blackcurrant aftertaste or not, I have my own magic, uncorked at last after thirty-seven years of waiting. I hope they appreciate that, both of them, mouths locked together and hands clasped. Now it is for them to do the talking. My part is at an end. I would like to think that theirs ends as happily. But that knowledge is beyond me now. I am subject to a different kind of chemistry. Evaporating blithely into the bright air, my own mystery approaches, and I see no phantoms, predict no futures, even the blissful present barely glimpsed - through a glass, darkly" (J. Harris "The blackberry wine", p. 332). The volatile and unstable nature of the narrative voice which withdraws from its story-telling role (Now it is for them to do the talking) is emphasized in this episode, collaborating with the negating effect of the above mentioned plot-strategy. Metaphorically, the story has been consumed just as the bottle 
of wine, seemingly leaving nothing behind (Evaporating blithely into the bright air), except for an aftertaste. Thus, not only a lack of inspiration, but also a lack of a story can become a story within the topos of writer's block.

\subsection{Unrealistic coincidence as a device}

Historically, fictional narratives often relied on coincidence without straining the reader's "suspension of disbelief". Wolf explains this in terms of literary teleology (2013: 53):

A persuasive purpose may also be seen at work in the compensatory potential of aesthetic illusion to make the recipient more readily accept a general tendency of aesthetic representations towards an 'unrealistic' surplus of coherence and meaning, i.e. to present worlds whose closure and meaningfulness (most conspicuously in the narrative use of coincidences and the convention of 'poetic justice' and teleological closure) could be regarded as deviating from the openness and contingency of life.

Yet, an overly conspicuous sequence of coincidences in a story may undermine its credibility. The metafictional potential of an overuse of coincidence, introduced on purpose, can be illustrated by Lodge's "Small world", a comic novel characteristically named by the author "an academic romance". Conceived as an extension of a "campus novel" to present the whole planet as a "global campus", the novel shows a multitude of literary scholars travelling all around the world to attend conferences, participate in workshops, etc. There is a continuous series of accidental meetings of the characters in different places, as well as coincidental revelations and discoveries that stretch the reader's belief to the extreme. The intertextual basis of the novel encompasses medieval Arthurian romances, particularly those centered on the Grail quest, and it is their structural patterns that are employed by the author. This is how Lodge himself explains (1992: 152) his technique in "The art of fiction": "It is also a novel that consciously imitates the interlacing plots of chivalric romances, so there is an intertextual justification, too, for the multiplicity of coincidences in the story". The effect is humorous, almost farce-like, as well as disruptive. It can be contrasted with the much more subtle effect of coincidence in Byatt's "Possession", where the humorous side of the story is reduced to mild irony and occasional satire, but some events are still seen as imitations of a chivalrous quest (e.g., Roland's rescue of Lady Bailey, which gave 
the protagonists a much desired chance to see Seal Court, the former residence of Christabel LaMotte). Whether it is a coincidence or not, the novel is also termed "a romance" by the author, while the characters' quest is definitely Grail-style (although never named so), allowing for an intertextual justification of unrealistic coincidences. This device is complemented with the mirror technique described in the following section.

\subsection{Embedded narratives and mise en abyme}

Embedded narratives (or story-in-a-story technique) have a long tradition in the world of literature. Their metafictional potential is realized when tension is created between the frames with the emphasis on the fictionality of the text, particularly when the device of "mise en abyme" is applied (or "mirror-text", as suggested by Bal in his "Narratology" (1999: 58). According to Prince (1982: 141), mise en abyme is the subplot that parallels the plot of that novel or reproduces it entirely on a small scale, while Bal speaks rather of the degrees of resemblance between the embedded and the primary narratives. As Bal correctly suggests, the "mirror-text" functions as a sign both to characters and readers, becoming an important interpretation key. A good example can be found in Byatt's "Possession", where the embedded tale of "Glass coffin" provides help (as well as another enigma) for Roland in his quest and simultaneously mirrors his own love story with Maud Bailey. The relationship of the other romantic couple in "Possession", Randolph Ash and Christabel LaMotte (the author of "Glass coffin"), also has some resemblance to the tale, as well as to the embedded narrative poem "Fairy Mélusine". Finally, two main stories (those of the $20^{\text {th }}$ century scholars Roland and Maud and the $19^{\text {th }}$ century poets Randolph and Christabel) have their own mutual parallels, which create, together with the numerous reflections in "mirror-texts", a mesmerizing effect, prescribed by the mise en abyme metaphor: setting into infinity. It does draw the attention to the artificiality of the text, but mildly so, working well with the rich mythological intertext of the novel.

As I mentioned in section 4.1, Randolph Ash perceives his love story with Christabel 
as "being trapped in a plot". In his case, this sentiment is expressed with an extensive use of academic vocabulary (since he is a literary scholar), adding another metareferential dimension to the text (although not metaleptically): it is a character self-reflexively analyzing his own attitude to the situation that reflects his own situation, actually using, among others, the term "self-reflexive": "Somewhere in the locked-away letters, Ash had referred to the plot of fate that seemed to hold or drive the dead lovers. Roland thought, partly with precise postmodernist pleasure, and partly with a real element of superstitious dread, that he and Maud were being driven by a plot or fate that seemed, at least possibly, to be not their plot or fate but that of those others. He tried to extend this aperçu. Might there not, he professionally asked himself, be an element of superstitious dread in any self-reflexive, inturned postmodernist mirror-game or plot-coil that recognises that it has got out of hand? That recognises that connections proliferate apparently at random, apparently in response to some ferocious ordering principle, which would, of course, being a good postmodernist principle, require the aleatory or the multivalent or the "free," but structuring, but controlling, but driving, to some - to what? - end. Coherence and closure are deep human desires that are presently unfashionable. But they are always both frightening and enchantingly desirable. "Falling in love," characteristically, combs the appearances of the world, and of the particular lover's history, out of a random tangle and into a coherent plot. Roland was troubled by the idea that the opposite might be true. Finding themselves in a plot, they might suppose it appropriate to behave as though it was that sort of plot. And that would be to compromise some kind of integrity they had set out with" (A. Byatt "Possession", p. 456). Doubting teleological loading of fiction, Roland fears that it imposes a certain pattern of behavior on himself undermining his free will and integrity. He later expands this thought and includes the whole Western world into the victims of the plot that he now calls "a romance": "All that was the plot of a Romance. He was in a Romance, a vulgar and a high Romance simultaneously; a Romance was one of the systems that controlled him, as the expectations of Romance control almost everyone in the Western world, for better or worse, at some point or another" (ibid., p. 460). As it has been mentioned, the novel 
itself is named "a romance", which renders Roland's ruminations ironic: he is literally trapped in a romance with no chance of escape. With cases as complex and manyfaceted as this one, it is futile to speak of a specific effect that the technique of mise en abyme may produce, apart from the permeating atmosphere of doubt and ambiguity. Even the happy ending that Roland and Maud experience is problematic with regard to the quoted passages: should it be treated as a demand of "a romance"? The metafictional liminality is particularly acute here since the coherence and closure of a fictional text are both questioned and celebrated.

In some cases a non-fictional embedded narrative can acquire a "mirror" quality, e.g., in "A short history of tractors in Ukrainian" by Marina Lewycka. Here a historical account of tractors, written by one of the characters, Mr Mayevskyj, an immigrant from Ukraine, provides an unexpected mirror to his own unhappy love story, creating rather a disturbing effect. Being an old widower and a British resident, he became attracted to and subsequently married a much younger Ukrainian woman (Valentina), who sought material gain and later abused him. The story of Ukrainian farming, including the horrors of Stalin's era and the Holodomor, is read out loud by Mr Mayevskyj to his daughter, the intradiegetic narrator, prompting the reader to draw a parallel between the abuses of Stalin and those of Valentina: "The retribution of Stalin was ruthless. Hunger was the tool he used. In 1932 the entire harvest of Ukraina was seized and transported to Moscow and Leningrad to feed the proletariat in the factories - how else was the revolution to be sustained? Butter and grain from Ukraina were on sale in Paris and Berlin, and well-meaning people in the West marvelled at this miracle of Soviet productivity. But in Ukrainian villages the people starved. This is the great unrecorded tragedy of our history, which only now is coming to light..."

"He stops, and gathers together his papers quietly. His glasses are perched low on his nose, the lenses so thick I can hardly see his eyes, but I fancy I catch a glint of tears. In the silence that follows, I can hear Valentina still chatting on the phone next door, and a faint beat of music corning from Stanislav's room. In the distance, the clock on the village church strikes seven" (M. Lewycka "A short history of tractors in 
Ukrainian", p. 81). The narrator's deep emotion is contrasted here to Valentina's (and her son Stanislav's) indifference, conveyed through the auditory imagery. Valentina's chattering and Stanislav's music clash with the solemn atmosphere, conditioned by the silence, the clock striking, and the tears in the eyes of Mr Mayevskyj. The embedded tractor story, from this episode on, modifies the tonality of the novel (where a sarcastic slant dominated from the beginning) and turns Mr Mayevskyj into a character who the reader might sympathize with, not only laugh at. The sarcasm never disappears completely, however, which is reflected in further tension between the diegesis and the embedded story: "The pen is mightier than the tea-towel, and Father writes his own revenge.

Never was the technology of peace, in the form of the tractor, transformed into a weapon of war, more ferociously than with the creation of the Valentine tank. This tank was developed by the British, but produced in Canada, where many Ukrainian engineers were skilled in the production of tractors. The Valentine tank was so named because it was first born into the world on the day of St Valentine in 1938. But there was nothing lovely about it. Clumsy and heavy with an old-fashioned gearbox, it was nevertheless deadly, indeed a true killing machine" (ibid., p. 136). The mise en abyme technique employed by Lewycka throughout the text is reinforced by the novel's title, which coincides with the name of the embedded tractor story, although it is not a selfbegetting story due to the absence of the plot-loop or a recursive metaleptic transgression.

\subsection{Magic realism}

The discussion of metafictional plot strategies would not be complete without mentioning of magic(al) realism, a type of contemporary fiction where marvellous, improbable, or fantastic events are featured within an otherwise realistic narrative. It used to be associated exclusively with postcolonial literature (particularly Latin American fiction), but the phenomenon has been globalized and is now wellrepresented in English-language prose (in works by Aimee Bender, Angela Carter, Joanne Harris, Toni Morrison, Salman Rushdie, and other authors). There is a tendency 
to affiliate magical realism with metafiction, primarily due to their ambiguity and a similar source of tension: liminality caused by magic vs. reality or fiction vs. reality configurations. It is, therefore, also a matter of metafictional potential, the realization of which depends on narrative peculiarities of the magical-realist text. As Waugh suggests (2001:38), concerning Márquez's "One hundred years of solitude" (which she does not consider to be metafictional): "Here the historical world and the alternative or fantasy world merge. In metafiction they are always held in a state of tension, and the relationship between them - between 'play' and 'reality' - is the main focus of the text".

The novel which seems to hit every target - postmodern, postcolonial, magical-realist, as well as "historiographic metafiction" in Hutcheon's terms (1988: 105-123) - is "Midnight's children" by Salman Rushdie, an allegorical story of Indian independence and partition. The above-mentioned tension is certainly there, while "the magical aspects of the narrative are essential to portray both the plot and the allegory" (Bowers 2005: 27). The text's deliberate ambiguity in historical and ideological matters, its palimpsest nature, and various improbable events are underpinned by a picturesque narrative strategy, saturated with self-reflexivity. It is encapsulated in the unreliable, self-conscious, highly reflexive narrator Saleem, who is a liminal figure himself, both in terms of his uncertain parentage and his mystical hour of birth. His storytelling, much indebted to Indian oral traditions, abounds in metanarrative commentary and emphatic addresses to the narratee (Padma, his fiancée), who sometimes metaleptically breaks into the narration. Fludernik (2009: 26) refers to similar usage of a narratee as a "metafictional ploy which uses irony to distance the reader from this fictional reader role". Rushdie's Padma, however, may both distance readers and create the effect of intimacy, depending on their cultural background and closeness / remoteness from India.

The novel's famous metaphor of "the pickles of history" seems to blend both magicalrealist aspects of the story and its metafictional status: chutnies that Saleem helps make contain "memories, dreams, ideas" that one day will "be unleashed upon the amnesiac 
nation", while his narrative is "chutnification of history", preservation of his own liminal, unreliable vision: "One day, perhaps, the world may taste the pickles of history. They may be too strong for some palates, their smell may be overpowering, tears may rise to eyes; I hope nevertheless that it will be possible to say of them that they possess the authentic taste of truth ... that they are, despite everything, acts of love" (S. Rushdie "Midnight's children", p. 533).

The metaphor anticipates the ultimate effect of the narrative: although its magical elements are conspicuously imaginary, its self-reflexivity draws attention to its fictional character, while the narrator's unreliability creates an ironic slant, the overall impression is that of an "authentic taste of truth", a transcending and illuminating quality of the entire text.

\subsection{Narrating as part of the plot}

In some cases narrative strategies exploit the tension inherent in metafictional liminality by working as a mediator between the diegetic and extradiegetic levels of the text without an actual metaleptic violation. Such mediating may be accompanied by the rearrangement of narrative roles or by sophisticated narrative games, such as introducing a fictitious author (as in "Pale fire" by V. Nabokov, "Everything is illuminated" by J.S. Foer, "Mrs Bradshaw's handbook" by T. Pratchett, and others). Moreover, a narrative disguise may develop a different role from the authorial one: as in the texts, mentioned in previous section, I-narrators may be presented as a commentator, translator, adaptor, or editor of the text. Thus, the narrating / the making of the book itself becomes a plot.

In "The princess bride" by William Goldman, for example, a sophisticated frame is created, foregrounding the extradiegetic I-narrator (also named "William Goldman"), who had heard the tale read to him as a child and now "abridges" it for publication by preserving "the good parts" (i.e. adventures) and cutting numerous digressions. The story is attributed to S. Morgenstern (a fictitious author), while in the narrator's 
childhood it was read to him by his father, who had skipped a lot to make it suitable for a ten-year-old. In his "abridgment" the narrator often surfaces with remarks and comments, while the ambiguous ending of the book is mediated between Morgenstern's, the father's, and the narrator's versions. The father's was classical "they lived happily ever after", while Morgenstern's created a cliff-hanger. The narrator comments on them both and then offers his own variant: "That's Morgenstern's ending, a "The Lady or the Tiger?"-type effect (this was before "The Lady or the Tiger?", remember). Now, he was a satirist, so he left it that way, and my father was, I guess I realized too late, a romantic, so he ended it another way. Well, I'm an abridger, so I'm entitled to a few ideas of my own. Did they make it? Was the pirate ship there? You can answer it for yourself, but, for me, I say yes it was. And yes, they got away. And got their strength back and had lots of adventures and more than their share of laughs. But that doesn't mean I think they had a happy ending, either. Because, in my opinion, anyway, they squabbled a lot, and Buttercup lost her looks eventually, and one day Fezzik lost a fight and some hot-shot kid whipped Inigo with a sword and Westley was never able to really sleep sound because of Humperdinck maybe being on the trail" (W. Goldman "The princess bride", p. 314)

The effect of this ending is both humorous (as are the majority of the abridger's "intrusions") and ambiguous. All three renderings of the story are summarized here, implying that the ultimate interpretation does not belong to one of them but to the combination of the three. The fictitious author's satirical view of a typical adventure fairy tale is underpinned by the narrator's metareference to the famous open-ended short story by Frank Stockton ("The lady, or the tiger?" published in 1882). The "Happy-ever-after" cliché renders the narrator's father as a "romantic", as well as problematizes the adaptation of "adult" literature for children: is a happy ending prerequisite for a tale told to a child? The narrator's own vision, given in its characteristic conversational style abundant in slang expressions, expands the "happyever-after" theme, offering a pessimistic vista of future events and engaging the narratee (You can answer it for yourself) as another interpreter of the story. In cases 
such as this it is hard not to agree with Williams, who objects to seeing self-reflexivity in fiction as a violation and not belonging to the story. Williams argues that the act of narration is central to diegesis and not "outside" of the plot and foregrounds what he calls a reflexive plot, which "inscribes its own mode, its own performative operation, while at the same time constatively depicting that act as a normal novelistic event" (2004: 25). Some readers, however, may still see such narrative twists as "digressions" and "asides", feeling irritated by them since they prevent them from learning "what happened next" as soon as possible. But there is a tendency to appreciate them as part of the whole story, which is explained, according to $\mathrm{Klimek}^{4}$, by the fact that "recipients seem to have learned to combine media awareness with the appreciation of aesthetic illusion" (2011a: 90).

\section{Metanarrative commentary}

The proper term for "digressions" and "asides" is metanarrative commentary (i.e., commentary about the narrative as part of the same narrative). Such commentary can be incorporated in the text both implicitly and explicitly, and it is renowned for its heterogeneity. It has long been used in literature, its most inconspicuous variants being metanarrative signs, termed so by Prince (1982: 125) in analogy to metalinguistic signs. Metanarrative signs perform organizational and interpretative functions, acting as "glosses on various parts of a text and the codes underlying them" (ibid.). Examples are easy to draw from classical British texts: e.g., from "Middlemarch", where George Eliot makes extensive use of them: "Your pier-glass or extensive surface of polished steel made to be rubbed by a housemaid, will be minutely and multitudinously scratched in all directions; but place now against it a lighted candle as a centre of illumination, and lo! the scratches will seem to arrange themselves in a fine series of concentric circles round that little sun. It is demonstrable that the scratches are going everywhere impartially and it is only your candle which produces the flattering illusion of a concentric arrangement, its light falling with an exclusive optical selection. These things are a parable" (G. Eliot "Middlemarch", p. 277). 
The sentence "These things are parable" refers to the preceding passage about the mirror and signals the transition from the allegory to its interpretation (provided immediately after). Metanarrative signs, such as this, develop into comments when they perceivably concern the whole text as an artefact (its composition, structure, characters, devices, process of creation, etc.). Another example from "Middlemarch" illustrates the point, since the authorial I-narrator compares her writing style with that of Henry Fielding: "But Fielding lived when the days were longer (for time, like money, is measured by our needs), when summer afternoons were spacious, and the clock ticked slowly in the winter evenings. We belated historians must not linger after his example; and if we did so, it is probable that our chat would be thin and eager, as if delivered from a campstool in a parrot-house. I at least have so much to do in unraveling certain human lots, and seeing how they were woven and interwoven, that all the light I can command must be concentrated on this particular web, and not dispersed over that tempting range of relevancies called the universe" (ibid., p. 45).

The phrase "we belated historians" implies the $19^{\text {th }}$ century novelists, and "our chat" is an ironically self-deprecating reference to their writing style, which the narrator thinks to be more laconic and less prone to digressions. The narrator states her concern with psychological depths in her characters, which predetermines the necessity to concentrate her effort in that sphere. Comments of this type were traditionally perceived as "asides" and "digressions" by readers, but, nevertheless, were favoured by authors, as we can see in the example above: criticizing Fielding's propensity for metanarrative, George Eliot makes use of it herself. Williams argues that such digressions "form (reflexive) pockets within the sequence of the plot" and they correlate with a different type of action: "their specific action is, very literally, the act of narration" (Williams 2004: 35).

\subsection{Scope of metanarrative commentary}

In contemporary fiction the application and effect of metanarrative commentary can be extremely varied. In radical texts like "Lost in the funhouse" they can be overtly 
disruptive, combined with an obtrusive presence of the narrator, and therefore metafictional to the extreme. In texts, where metafictional strategies are much more subtle, they can crop up on different levels, beginning with the metalinguistic one, as in the following example from "Possession": "And yet, natures such as Roland's are at their most alert and heady when reading is violently yet steadily alive. (What an amazing word "heady" is, en passant, suggesting both acute sensuous alertness and its opposite, the pleasure of the brain as opposed to the viscera - though each is implicated in the other, as we know very well, with both, when they are working.)" (A. Byatt "Possession", p. 511). The commentary on the lexical unit "heady" is parenthetically detached here to create a "reflexive pocket", in which the first-person plural "we" includes the narrator and the readers, both involved in the same cognitive exercise (as we know very well), prompted by linguistic signs.

The next level, which can be called metanarrative proper, often addresses critically the nature of the text: its title, themes, style, techniques, and so on. It may occur in various places in the text, including even footnotes, which can sometimes constitute an important part of the narrative strategy (as in the Discworld series by Terry Pratchett or "Jonathan Strange \& Mr Norrell" by Susanna Clarke). The example below demonstrates how it can dominate the very beginning of a novel, "predicting" some features of the narrative: "This is a story about magic and where it goes and perhaps more importantly where it comes from and why, although it doesn't pretend to answer all or any of these questions. It may, however, help to explain why Gandalf never got married and why Merlin was a man. Because this is also a story about sex, although probably not in the athletic, tumbling, count-the-legs-and-divide-by-two sense unless the characters get totally beyond the author's control. They might" (T. Pratchett "Equal rites", p. 1). Apart from setting the thematic direction for the story (that of gender and magic), this beginning achieves a humorous effect by suggesting that characters might get beyond the author's control. This idea is quite topical for $20^{\text {th }}$ century fiction, where the relationship between the author and the characters is viewed from all possible angles (including the metaleptic possibility). Intertexual references to Gandalf and 
Merlin create another "reflexive pocket", in which the implied author and readers belong to the same world, ontologically different from the storyworld.

The ultimate level of metanarrative commentary is the incorporation of the whole pieces of literary criticism in the text. They can be embedded as articles or lectures attributed to characters, introduced through characters' speech or presented by the narrator. The examples can be found in texts by Antonia Byatt, Stephen Fry, David Lodge, and others. In Lodge's "Small world" an old scholar called Miss Maiden provides the information concerning Lodge's own main intertextual sources for his novel in her conversations with other characters:

"I did my Master's thesis on Shakespeare and T.S. Eliot."

"Then you are no doubt familiar with Miss Weston's book, From Ritual to Romance, on which Mr Eliot drew for much of the imagery and allusion in The Waste Land?" "Indeed I am," said Persse.

"She argued," Miss Maiden continued, not at all deterred by this answer, "that the quest for the Holy Grail, associated with the Arthurian knights, was only superficially a Christian legend, and that its true meaning was to be sought in pagan fertility ritual. If Mr Eliot had taken her discoveries to heart, we might have been spared the maudlin religiosity of his later poetry" (D. Lodge "Small world", p. 12).

Although the exchange creates a comical situation at this point in narration, the information it contains will be crucial for the understanding of the novel's ending. Thus, Lodge playfully lays bare his own methods, although it is not immediately seen by the reader. The novel also includes a talk on structuralism delivered in a dialogue, and some conference papers dealing with erotic coding of writing, reading, and interpretation. It is due to the arrival of such texts that scholars started introducing specific terms for novels abounding in criticism: "theoretical fiction" (Currie) and "academic metafiction" (Székely). Tolan (2007) in her discussion of Margaret Atwood's novels outlines a possible conflict that such fiction entails (she calls it "a postmodern or metafictional conflict"), consisting in generating tension between the 
criticism in the novel and its actual critics: "The text is no longer a passive recipient of theoretical interpretation, but enters into a dynamic relationship with the theoretical discourse, frequently anticipating future developments yet to be articulated by an academic discourse" (Tolan 2007: 1). Whether this conflict is going to be dramatic or not, it certainly signals another step in constant rethinking of the status of fiction and possibilities of its interpretation.

Quite a remarkable case of metafictional commentary of this level can be observed in Terry Pratchett's Discworld series, where one of the basic elements of the universe is called "narrativium". Theories that focus on narrative causality are studied at Unseen University, a prominent school of magic on Discworld. Narrativium's constant presence in Discworld's universe makes sure events are treated as stories and dictates how they should unfold: "People think that stories are shaped by people. In fact, it's the other way around. Stories exist independently of their players. If you know that, the knowledge is power" (T. Pratchett "Witches abroad", p. 8). This sentiment is strikingly similar to the one discussed above, i.e., "being trapped in a plot" as it is manifested in "Possession", since it problematizes the issue of free choice and integrity. Moreover, the power of narrative can be used by villains resorting to magic.

As Kanchura points out in her thesis on Pratchett's postmodern textuality (Канчура 2012: 145), characters in the series' novels fall into several categories: those who unwittingly follow the narrative clichés; those who consciously adhere to them; those who manipulatively use narrative patterns to their own benefit, and those who oppose narrative imperatives in order to liberate themselves and others. The entire plot of the novel "Witches abroad" revolves around the conflict caused by different approaches to stories and narrative patterns, expanding metafictional commentary to world-building and structuring proportions. This phenomenon is characteristic of contemporary fantasy fiction that tends to incorporate theoretical concepts into the magic premise of a secondary world. Readers may be both amused and intellectually challenged by such strategies, while their authenticating effect, as with narrative metalepsis, depends on 
the presence / absence of mediating quality in a specific storyworld.

\subsection{Metaphorizing reading and writing}

Metanarrative commentary often includes metaphorized portrayals of the relationship between the representatives of narrative levels. The author or narrator can be seen as god, architect, ventriloquist, puppeteer, sorcerer, cook, "swallower of lives", etc. Other bountiful objects for metaphorization are the act of writing (compared to painting, building, weaving, cooking, dancing, having sex, etc.) and the act of reading (unravelling, detecting, deciphering, communicating, getting lost in the woods, eating, having sex, etc.). Erotic coding of reading, for example, is presented in a sophisticated way through the juxtaposition with sensual eroticism in a metanarrative commentary in "Possession": "It is possible for a writer to make, or remake at least, for a reader, the primary pleasures of eating, or drinking, or looking on, or sex. Novels have their obligatory tour-de-force, the green-flecked gold omelette aux fines herbes, melting into buttery formlessness and tasting of summer, or the creamy human haunch, firm and warm, curved back to reveal a hot hollow, a crisping hair or two, the glimpsed sex. They do not habitually elaborate on the equally intense pleasure of reading. There are obvious reasons for this, the most obvious being the regressive nature of the pleasure, a mise-en-abime even, where words draw attention to the power and delight of words, and so ad infinitum, thus making the imagination experience something papery and dry, narcissistic and yet disagreeably distanced, without the immediacy of sexual moisture or the scented garnet glow of good burgundy" (A. Byatt "Possession" p. 510511). This commentary seemingly refers to fiction in general, but it implies "the intense pleasure of reading" experienced by Roland (as seen later in the text). It discusses literary techniques with the help of elevated vocabulary (including French and Latin expressions): "obligatory tour-de-force", "regressive nature of the pleasure", "a miseen-abîme", "narcissistic and yet disagreeably distanced". The juxtaposition to sensuality of eating and having sex, introduced through vivid verbal images representing these phenomena metonymically, underpins the "dryness" of reading on the one hand, and yet ascribes it the same level of intensity. The passage itself 
intrinsically emphasizes the pleasure of reading through the rhythm and arrangement of words, creating yet another "mirror" in the novel.

In the Discworld novel "Witches abroad", where stories are viewed as powerful entities shaping human lives, they are conceptualized as animals that have been evolving through history: "Stories, great flapping ribbons of shaped space-time, have been blowing and uncoiling around the universe since the beginning of time. And they have evolved. The weakest have died and the strongest have survived and they have grown fat on the retelling... stories, twisting and blowing through the darkness" (T. Pratchett "Wicthes abroad", p. 8). The effect is disturbing because the metaphor hints at the potential danger these stories carry, thus making the protagonists' task more daring (since they are going to oppose narrative imperatives and those who attempt to use them for their own gain). This image is reinforced by the further comparison of stories with parasites: "Stories are a parasitical life form, warping lives in the service only of the story itself" (ibid., p. 8). The image of stories presented as dangerous parasitical creatures is maintained throughout the novel contributing to the growing suspense. The protagonists (who are also the eponymous witches) feel their presence and the threat they pose. The latter is conceptualized in the metaphor of "feeding people to stories", which dehumanizes characters, reducing them to the level of "food" or "things". This concept comes up as the main matter of debate during the confrontation between the protagonist and the antagonist in the climax of the novel: "That's how it works when you turn the world into stories. You should never have done that. You shouldn't turn the world into stories. You shouldn't treat people like they was characters, like they was things. But if you do, then you've got to know when the story ends" (ibid., p. 270).

Quite predictably, another common metaphor from the citation given above, equates the world and the story. The conceptual metaphor STORY IS A WORLD is ubiquitous in fiction in general and in metafictional narratives in particular, cropping up in numerous modifications. Besides, it is extensively exploited in literary criticism and linguistic research. In fiction, the metaphor may work both ways and, when used self- 
reflectively, often creates a slightly ironic effect. Even in texts, generally devoid of metafictional strategies, the metaphor may occur to undermine the reader's immersion in the story, e.g., in situations where characters remark that they actually feel like characters in a story, as it can be seen in Roger Zelazny's "The sign of the unicorn": "I've a peculiar feeling that I may never see you again. It is as if I were one of those minor characters in a melodrama who gets shuffled offstage without ever learning how things turn out" (R. Zelazny "The sign of the unicorn", p. 109). Although not strictly metaleptic, such observation may feel disruptive to the reader, especially in the light of the protagonist's tongue-in-cheek reply, developing the "inside the story" metaphor, which goes as follows: "My own role sometimes makes me want to strangle the author. But look at it this way: inside stories seldom live up to one's expectations. Usually they are grubby little things, reducing down to the basest of motives when all is known. Conjectures and illusions are often the better possessions" (ibid.).

At the same time, metafictional imagery of this kind constructs the sense of connectivity uniting all the participants of the textual continuum (author, narrator, character, reader, etc.). They all operate within one system, since they are interwoven in one metaphorical web in the act of creating the story. From the cognitive perspective, it is plausible to assume that such conceptual metaphors constitute what Kövecses referred to as the "metaphor system" (2010: 149-167). Both systems that the scholar describes, the GREAT CHAIN metaphor and the EVENT STRUCTURE metaphor, are applicable here. This perspective is beyond the scope of the present paper but it suggests a promising field for further inquiry into metafictional metaphorizing.

\section{Metafictional parody}

Parody, used in literature since the ancient times, can become a powerful metafictional tool. Rose (1979: 66), who studied parody from this perspective, states that both parody and metafiction "undermine naive views of the representation of nature in art, and are able to demonstrate critically the processes involved in the production and reception from within the literary text". Parody can be regarded as metafictional when its object 
is fictional discourse or, in some cases, a literary genre. Waugh (2001: 64) considers such parody to be a positive change, since it deconstructs a set of fictional conventions which have become automatized, and by doing so clears a path for a new set. Closely connected with metafictional parody is the notion of postmodern pastiche, which is also noted for its metatextual and metagenre potential (Бербенець 2008). It is distinct from metaparody, though, which relies rather on conflicting and blending points of view presented in the parodic text (for metaparody see Pleshakova 2016).

On the level of the discourse, numerous parodies and pastiches can be found in the novels by Margaret Atwood, Julian Barnes, William Golding, David Lodge, and many others. Atwood's "The blind assassin", for example, has been viewed as a "hybridized literary parody" since it contains a fragmented embedded science fiction story, as well as clippings from magazines and comic books, constructing thus "an ironic metanarrative which analyzes the way in which popular sites of representation construct our perception, desires, and values" (Dvorak 2006: 127). Fowles' "The French lieutenant's woman" is regarded in Hutcheon's monograph on parody as a revaluation of parody itself due to its juxtaposition of the conventions of the Victorian and the modern novel (2000: 31 ). It is significant that irony which accompanies parodic metafiction "can cut both ways" (ibid., 33), that is, exposes the problematic issue of both texts that meet in the narrative.

To illustrate this, let us regard how metatextual parody and pastiche are used in Lodge's "The British Museum is falling down", which is structured (parodying Joyce's "Ulysses") around one day in the life of the protagonist, Adam Appleby. Adam, who is himself a scholar, undergoes a series of events and encounters as he attempts to work on his thesis on English literature in The British Museum Reading Room. The text contains ten passages parodying the idiostyles of James Joyce, David Lawrence, Franz Kafka, Virginia Woolf, and other writers, the effect being that of enhanced selfreflexivity, rendering the protagonist's anxiety "fictional" and self-imposed. The citation below demonstrates how it is achieved through the parody of Lawrence: "He 
passed through the narrow vaginal passage, and entered the huge womb of the Reading Room. Across the floor, dispersed along the radiating desks, scholars curled, foetuslike, over their books, little buds of intellectual life thrown off by some gigantic act of generation performed upon that nest of knowledge, those inexhaustible ovaries of learning, the concentric inner rings of the catalogue shelves" (D. Lodge "The British Museum is falling down", p. 44).

Lawrence's typical conflict of mind and body is rendered here through the metaphor LIBRARY IS A FEMALE BODY, the verbal manifestations of which (narrow vaginal passage, the huge womb of the Reading Room, scholars curled, foetus-like, over their books) create a slightly humorous effect due to the visual associations they produce. The mind-and-body theme is particularly resonant for Adam, since he and his wife, being Catholics, are banned from contraception and live under the constant threat of a new pregnancy. The fertility image is transposed here onto the "mind" (some gigantic act of generation performed upon that nest of knowledge), and the passage goes on to show the scholars' women: "And they resented the warm womb of the Museum which made them poor and lonely, which swallowed up their men every day and sapped them of their vital spirits and made them silent and abstracted mates even when they were at home. And the women sighed for the day when their men would be expelled from the womb for the last time, and they looked at their children whimpering at their feet, and they clasped their hands, coarsened with detergent, and vowed that these children would never be scholars" (ibid., p. 45).

The "fertile mind" image is reversed here, and "the womb" turns into a destructive organism that "saps" vitality out of men. Thus, the Lawrence-style passage reflects Adam's own preoccupations with sexuality and intellectuality. The parody can be read as Adam's interior monologue, triggered by the necessity to concentrate on Lawrence's work; or it can be viewed as part of self-reflexive narrative, constantly highlighting the interpenetration of fiction and reality. Other parodic passages in the novel take relish in similar ambiguities, although they can be altogether missed by an average reader, 
with the exception of the epilogue in which Molly Bloom's famous monologue from "Ulysses" is imitated. This episode features Barbara (Adam's wife) as a focalizer for the first time in the novel, and her thoughts as she is falling asleep are rendered with a gradual decrease in adhering to literary conventions, ending up in a stream-ofconsciousness with free-flowing syntax devoid of punctuation. This parodic coda casts a new, female, perspective on the main themes of the novel, but still emphasizes its reflexivity and ambiguous uncertainty by the constant repetition of the word "perhaps" (whereas Molly's refrain was "yes"). This yes / perhaps opposition ironically reflects the shift from the feeling of completeness associated with earlier fiction to a more contemporary feeling of insecurity and uncertainty, encapsulated in postmodern sensitivity: "I said you're not very optimistic he said perhaps it's better not to be I said I'm going to be famous and earn lots of money he said perhaps you won't love me then I said I'll always love you he said I'll prove it every night he kissed my throat perhaps you think that now I said but I couldn't keep it up perhaps we will be happy I said of course we will he said we'll have a nanny to look after the children perhaps we will I said by the way how many children are we going to have as many as you like he said it'll be wonderful you'll see perhaps it will I said perhaps it will be wonderful perhaps even though it won't be like you think perhaps that won't matter perhaps" (ibid., p. 161). Simultaneously, both Molly's and Barbara's interior monologues, in spite of their placement in the corresponding texts, fail to provide any final "truth" or resolution (see Lawrence 1981: 203-209). On the contrary, they undermine any certainties that the previous narrative might have established by a pronounced stylistic counterpoint. Thus Lawrence's remark about Ulysses that "the whole book has cautioned us not to trust one version of things more than another" (1981: 207) is equally applicable to Lodges' parody of James Joyce's masterpiece.

On the level of the genre, parody has been extensively used to expose standardized conventions of a particular genre. Among popular targets are detective stories and thrillers: the possibilities of their subversion have been demonstrated to the world by the virtuosity of Umberto Eco's novels. In English-language literature, Peter Ackroyd 
has experimented with metafictional transformations of both detective and biography ("Chatterton", "Hawksmoor", "The last testament of Oscar Wilde", etc.). Historiographic metafiction (such as "The French lieutenant's woman" and "Midnight's children") can be viewed as the reinventing of historical novels. All-time favourite targets of parody are Shakespearean plays, particularly his great tragedies. For instance, the analysis of pastiches on "Hamlet" demonstrated how the range of possibilities generated by the original text's heterogeneity is exploited and recontextualized by this technique (Бербенець 2008).

The "cleansing" effect of metagenre parody is best illustrated by Terry Pratchett's Discworld series. The first novels of the series continuously attacked and parodied fantasy fiction clichés, but later on a new style began to emerge, in which postmodern intertextuality still played an important part, while metafictional sensibility was generally reduced. One of the significant stages in this process was the genre fusion of fantasy and detective fiction with simultaneous parodying of both. Several "urban fantasy" novels were created in this manner, beginning from "Guards! Guards!", where the metafictional vein is the strongest. Two main characters of this series, Sam Vimes and Captain Carrot, represent the stereotypes of detective and fantasy fiction respectively. Vimes is a detective, the Captain of the Night Watch (a malfunctioning police force in the city of Ankh-Morpork gradually restoring its importance); while Carrot is an heir to the throne, a "long-awaited king" of the fantasy tradition. But Vimes does not turn into a cold intellectual, elegantly unravelling crime problems; his image is built around the metaphor of the CITY AS A WOMAN, his woman, who he understands and protects. Carrot, in his turn, never ascends the throne of AnkhMorpork, but turns into a highly effective Watch officer, proud of his work for the city. The development of these characters is interspersed with reflexive parodies of detective and fantasy discourses, as in this example, taken from "Feet of clay" and attacking Sherlock Holmes: "He had a jaundiced view of Clues. He instinctively distrusted them. They got in the way. And he distrusted the kind of person who'd take one look at another man and say in a lordly voice to his companion, 'Ah, my dear sir, I can tell you nothing 
except that he is a left-handed stonemason who has spent some years in the merchant navy and has recently fallen on hard times,' and then unroll a lot of supercilious commentary about calluses and stance and the state of a man's boots, when exactly the same comments could apply to a man who was wearing his old clothes because he'd been doing a spot of home bricklaying for a new barbecue pit, and had been tattooed once when he was drunk and seventeen and in fact got seasick on a wet pavement" (T. Pratchett "Feet of clay", p. 142).

Captain Vimes is a focalizer here, contemplating the importance of clues - the word itself is deliberately capitalized to signal an ironic attitude to their formulaic usage in crime fiction. The allusion to "the person with a lordly voice" is immediately identifiable by most readers, as well as a typical case of "deduction", deconstructed here by Vimes. To undermine such "deductions" further, Vimes' own investigation method is given (with a characteristic slip into free indirect discourse): "The real world was far too real to leave neat little hints. It was full of too many things. It wasn't by eliminating the impossible that you got at the truth, however improbable; it was by the much harder process of eliminating the possibilities. You worked away, patiently asking questions and looking hard at things. You walked and talked, and in your heart you just hoped like hell that some bugger's nerve'd crack and he'd give himself up" (ibid.). Here the allusion to Sherlock Holmes stories is represented by a transformed quotation (It wasn't by eliminating the impossible that you got at the truth, however improbable; it was by the much harder process of eliminating the possibilities), and the language itself in stark contrast with Vimes' "street talk". The paradox of "the real world being far too real" emphasizes the fictionality of a Holmes-style detective by stressing the "realistic" methods employed by Vimes. Yet, due to genre interaction, they are not at all realistic: inheriting fantasy's generic tendency for harmonizing models, Vimes stories rely heavily on mythological patterns, namely the sacred unity of the king and the land (Тихомирова 2012: 179). In the series, it transforms into the pattern "the policeman and the city are one", which gradually acquires an equally sacred status. 


\section{Discussion and conclusion}

According to Hutcheon (1988), the "metafictional paradox" of self-reflexive narratives lies in the fact that they demand both detachment and involvement from the reader. Practically the same notions are used by Wolf when he describes the ambiguous nature of aesthetic illusion, stating that it relies on the recipient's imaginative immersion in the representation, as well as keeping a rational distance from it (2013: 14-19). This is hardly surprising since metafiction depends on undermining aesthetic illusion and seeks ways to engage the reader, while enhancing their critical awareness. It is a dynamic process, steeped in liminal tension: if the critical side prevails, the result tends to be disruptive, but if the illusionist side takes over (without losing the metafictional edge), the strategy ensures an authenticating effect.

As the paper demonstrated, contemporary English-language fictional narratives creatively exploit metafictional liminality. A wide range of narrative strategies are employed by authors to draw the reader's attention to the "seams" of the text, effectively creating additional ontological layers of meaning by problematizing the interaction between fiction and reality. These seams are foregrounded in a variety of ways, both explicit and implicit. The notion of a "boundary" is often exploited by scholars (as in the boundary between narrative levels) to describe this process, while the notion of "transgression" is employed to pinpoint those narrative situations when the boundary is destabilized. Narrative metalepsis is seen as the most radical way of transgressing this boundary or, in other words, of defying the assumed logic of representation. The correlation between fictional worlds belonging to the same text is at the core of metaleptic transgression, especially in the genres that depend on the juxtaposition of storyworlds. The paper has shown that in fantasy fiction, for example, metalepses do not necessarily break aesthetic illusion: in certain cases, when a metaleptic shift acquires the status of a mediator, they may even authenticate the storyworld. Being a gradable phenomenon, metalepsis is realized through narrative strategies that exploit its perceived "impossibility" and / or unexpectedness with varying degrees of illusionbreaking. Effects of metaleptic transgression are conditioned by the degree of its 
disruptiveness, as well as the ontologically and contextually contingent hermeneutic situation.

Whether it is essentially metaleptic or not, the narrative loop of a self-begetting novel foregrounds the process of narrativization itself, encouraging readers to question their perceptions and even apply the same narrative approach to their own experiences by analogy. General skepticism about one's existence and reality that Klimek attributes to the effects of metalepsis in fantasy fiction (2011b: 37), can be named among the effects of metafictional liminality in all of its manifestations, regardless of the genre. A deliberate use of coincidences, for instance, may prompt ramifications about synchronicity and probability of events, both in fiction and real life. Representation of coinciding events through metafictional strategies dynamically interacts with aesthetic illusion. Structurally, liminal tension may be also increased by sophisticated framing and polyphonic fragmentation, all of which highlight the act of story-telling itself. The mirror technique of mise en abyme foregrounds essential elements of the plot and characterization creating a similar philosophic dimension: characters being aware of narrative patterns influencing their existence may prompt readers to analyze the ways they are governed by such patterns themselves and reveal accompanying cognitive fallacies. Embedding mise en abymes, authors explore the textual potential for fractality, both on the structural and stylistic levels, experimenting with the recursiveness and reflexivity. Narrative loops and embedded stories often employ the topos of a writer's block, which narrativizes creative crisis and inspiration (or the lack of it).

The act of story-telling has been linguistically foregrounded in numerous metafictional narrative games and flamboyantly metaphorized, with vivid analogies attributed to all participants of the process. Viewed as interconnected parts of one great chain or system, they thrive in the ongoing process of narrativization and are mutually stimulating. The active role of every participant of the story-telling situation is an underlying idea of contemporary metafictional narratives. An active approach 
presupposes, once again, both immersion and critical awareness. Within metafictional parody, for example, it clears the path for a renewed vision. When two (or more) sets of literary conventions meet in a parodic text, multifaceted irony directs the process of recontextualization, wherein liminal tension is predetermined by a critical distance between the parodied text and the new work (Hutcheon 2000: 32). Both metafictional parodies and pastiches use this critical distance to engage the reader in reassessing conventions of genres and forms and revitalizing their potential for meaning-making. This revisiting often borders on revisioning, as in the postmodern fantasy parodies of Terry Pratchett that offer new perspectives on textuality in the context of worldbuilding.

Thus, stylistic effects, produced by metafictional narrative techniques, although being hugely dependent on the specific context, often tend to have the air of paradox: since they interact with aesthetic illusion, they combine ironic distancing with the sense of unity or even intimacy of belonging to the same storyworld or system. The former side, the ironic loading of metafiction due to its inherent incongruity, accounts for humorous and subversive effects, enhanced by the linguistically foregrounded unexpectedness (shifts in the point of view characters, collocative clashes, etc.). The sense of belonging or being connected to the storyworld, on the other hand, results from the authenticating effects of metafictional strategies. The state of immersion that predetermines this condition may also entail a rather disturbing effect, as it has been demonstrated through examples from fantasy fiction, since belonging to a secondary world where it is possible to be trapped in imaginary domains (not necessarily pleasant) may be perceived as destabilizing and insecure. These domains frequently acquire ekphrastic nature, which makes intermediality a fruitful field for further research of metafictional narratives.

To conclude, it is worthwhile to consider the general significance of the phenomenon under scrutiny. Peters has offered a hypothesis that parody has been instrumental in the development of the British novel in general. Proceeding from Bakhtin's theory of 
dialogism, according to which the novel develops by parodying sets of existing conventions, Peters (2002: 192-193) places this evolutionary process into feminist and metafictional contexts and concludes that women's discourse was essential for the evolution of novel as a genre. According to Peters, this evolution included privileging of the female way of narrativizing social "reality", both upholding and dismounting literary conventions. To extend this idea, let us include all sorts of underpriviledged voices that establish their own narratives through parody of the dominant discourse. Metafiction, parody, magical realism, fantasy, and other landmarks in the landscape of contemporary fiction are indispensable in the literary quest for identity and writing about the self. The ability to reflect oneself has been called the decisive characteristic of the human condition, while metareference is the chief manifestation of this significant faculty (Mahler 2011: 71).

The variety and originality of metafictional strategies are astonishing. Umberto Eco commented back in the 1990s that postmodern fiction subjected readers to all kinds of "metafictional depravity" (1994: 126). But this kind of "depravity" prevails: metafictional strategies are extensively employed in different genres and their hybrids; non-fictional discourses intermingled with metafictional ones (as in Mark Crick's "Kafka's soup: A complete history of world literature in 14 recipes", where metafictional parody has been combined with the culinary discourse). Readers' involvement is called for, even in the formats that are traditionally non-interactive (as in Karen Joy Fowler's "The Jane Austen book club", which ends with "questions for discussion" suggested by the characters of the novel for the readers (Fowler 2007: 284286). Strategies exploiting liminal tension of aesthetic illusion in other media are a commonplace phenomenon, and they have been given a lot of academic attention. Films, animation, graphic novels, picture books, and computer games provide ample material for the study of metareferentiality. All in all, it is doubtful that this proliferating creative urge can be put down to undermining great stories in order to clear new paths or simply overcoming "the crisis of presentation". If we view reflexivity as an intrinsic feature of fiction, its "survival trait", as well as the decisive 
characteristic of the human condition, then metafiction can be regarded as selfcelebration, or, as Williams (2004: 22) calls it, self-advertisement, since narratives foreground their own the necessity and desirability. Thus, innumerable stylistic effects, intricate metaphoric webs, and imaginative plot arrangements serve as indispensable tools in metafictional advertising campaigns, ultimately aimed at the survival and promotion of the pleasure of reading.

\section{Notes}

1. When the criterion for the classification is the narrative agent who transgresses one of the levels, then metalepses are grouped into authorial / narratorial / lectorial (see Fludernik 2003: 389).

2. Klimek here treats fantasy fiction as a subgenre of the fantastic, relying on Todorov's definition of the marvellous (see Klimek 2011a: 77-78). In my paper, I refer to the genre of fantasy as an umbrella term that covers all texts that are based on magical secondary worlds (storyworlds). The term "metareference" that Klimek uses is a transmedial equivalent of metafiction. It is applied throughout the volume in which her paper is published, which deals with the metareferential turn in contemporary media.

3. Klimek classifies metalepsis as descending and ascending, according to its direction in the hierarchy of narrative levels (see 2011b: 24).

4. This remark is made in terms of fantasy fiction, but it can be easily applied to fiction in general, since media-awareness of which the scholar writes is indeed omnipresent.

\section{References}

Abrams, M. \& Harpham, G. (2012). A glossary of literary terms. Boston: Wadsworth. Allen, W. (1986). Side effects. New York: Ballantine.

Atwood, M. (2000). The blind assassin. Toronto: McClelland \& Stewart.

Bal, M. (1999). Narratology: Introduction to the theory of narrative. Toronto: University of Toronto Press. 
Berbenets', L.S. (2008). Pastiche and peculiarities of artistic representation in postmodern fiction. Thesis for the candidate degree in philology. Speciality $10.01 .06-$ theory of literature. Kyiv: T.H. Shevchenko institute of literature, NAS of Ukraine. / Berbenets' L.S. Pastysh i osoblyvosti khudozhn'oyi reprezentatsiyi v literaturi postmodernismu. Dysertatsiya na zdobuttya vchenoho stupenya kandydata filolohichnykh nauk. Spetsial'nist' 10.01 .06 - teoriya literatury. Kyyiv: Instytut literatury imeni T.H. Shevchenka NAN Ukrayiny. / Бербенець Л.С. Пастиш $i$ особливості художньої репрезентаиії в літературі постмодернізму. Дисертація на здобуття вченого ступеня кандидата філологічних наук. Спеціальність 10.01.06 - теорія літератури. Київ: Інститут літератури ім. Т.Г. Шевченка НАН України.

Bowers, M.A. (2005). Magic(al) realism. London-New York: Routledge.

Briggs, S. \& Pratchett, T. (2001). Nanny Ogg's cookbook. London: Corgi Books.

Byatt, A.S. (1990). Possession. A romance. New York: Random House.

Currie, M. (2004). Difference. London-New York: Routledge.

Currie, M. (1995). Metafiction. New York: Longman.

Dvorak, M. (2006). Margaret Atwood's humor. In The Cambridge companion to Margaret Atwood. Howells, C.N. (ed.). Cambridge: Cambridge University Press, p. 114-129.

Eco, U. (1994). Six walks in the fictional woods. Harvard: Harvard University Press. Eliot, G. (2007). Middlemarch. London: Vintage Books.

Fludernik, M. (2003). Scene shift, metalepsis, and the metaleptic mode. In Style, 37 (4), p. 382-400.

Fludernik, M. (2009). An introduction to narratology. London-New York: Routledge. Fowles, J. (1981). The French lieutenant's woman. New York: Signet.

Fowler, K.J. (2007). The Jane Austen book club. New York: Plume.

Gass, W.H. (1980). Philosophy and the future of fiction. In Syracuse scholar (19791991), 1 (2). Available at: https://surface.syr.edu/suscholar/vol1/iss2/3

Genette, G. (1983). Narrative discourse. An essay in method. Ithaca-New York: Cornell University Press. 
Goldman, W. (1974). The princess bride: S. Morgenstern's classic tale of true love and high adventure. New York: Ballantine Books.

Gregoriou, C. (2014). The linguistic levels of foregrounding in stylistics. In The Routledge handbook of stylistics. Burke, M. (ed.). London-New-York: Taylor \& Francis, p. 87-100.

Hanebeck, J. (2017). Understanding metalepsis: The hermeneutics of narrative transgression. Berlin-Boston: De Gruyter.

Harris, J. (2001). The blackberry wine. Edinburgh: Black Swan.

Hutcheon, L. (1980). Narcissistic narrative. The metafictional paradox. Waterloo: Wilfrid Laurier University Press.

Hutcheon, L. (1988). A poetics of postmodernism. History, theory, fiction. New York: Routledge.

Hutcheon, L. (2000). A theory of parody: The teachings of twentieth-century art forms (Reprint edition). Urbana-Chicago: University of Illinois Press.

Ingersoll, E.G. (2001). Engendering metafiction: Textuality and closure in Margaret Atwood's Alias Grace. In American review of Canadian studies, 31 (3), p. 385-401.

Kanchura, Ye.O. (2012). Modeling of textualized world in the fantasy novels by Terry Pratchett. Thesis for the candidate degree in philology. Speciality 10.01.04 - literature of foreign counties. Mykolaiv: Petro Mohyla Black Sea state university. / Kanchura, Ye.O. Modelyuvannya tekstualizovanoho svitu $v$ romanakh-fentezi Terri Pretchetta. Dysertatsiya na zdobuttya vchenoho stupenya kandydata filolohichnykh nauk. Spetsial'nist' 10.01.04 - literatura zarubizhnykh krayin. Mykolayiv: Chornomors'kyj derzhavnyj universytet imeni Petra Mohyly. / Канчура Є.O. Моделювання текстуалізованого світу в романах-фентезі Террі Претчетта. Дисертація на здобуття вченого ступеня кандидата філологічних наук. Спеціальність 10.01.04 - література зарубіжних країн. Миколаїв: Чорноморський державний університет імені Петра Могили.

Kellman, G. S. (1980). The self-begetting novel. New-York: Columbia University Press.

Klimek, S. (2011a). Fantasy fiction in fantasy fiction: Metareference in the Otherworld 
of the Faërie. In The metareferential turn in contemporary arts and media. Forms, functions, attempts at explanation. Wolf, W. (ed.). Amsterdam-New York: Rodopi, p. 77-95.

Klimek, S. (2011b). Metalepsis in fantasy fiction. In Metalepsis in popular culture. Kukkonen, K. \& Klimek, S. (eds.). Berlin-New York: Walter de Gruyter, p. 22-40.

Kövecses, Z. (2010). Metaphor: A practical introduction. Oxford: Oxford University Press.

Lawrence, K. (1981). The odyssey of style in Ulysses. Princeton: Princeton University Press.

Leech, G.N. \& Short, M. (2007). Style in fiction: A linguistic introduction to English fictional prose. 2nd ed. London: Pearson Education.

Lewycka, M. (2006). A short history of tractors in Ukrainian. London: Penguin books. Lodge, D. (1983). The British Museum is falling down. London: Penguin Books. Lodge, D. (1984). Small world: An academic romance. London: Secker \& Warburg. Lodge, D. (1992). The art of fiction. New York: Viking.

Mahler, A. (2011). Writing on the writer's block: Metaization and/as lack of inspiration. In The metareferential turn in contemporary arts and media. Forms, functions, attempts at explanation. Wolf, W. (ed.). Amsterdam-New York: Rodopi, p. 51-76.

McHale, B. (1987). Postmodernist fiction. New York: Methuen.

Nelles, W. (1997). Frameworks: Narrative levels and embedded narrative. New York: Peter Lang.

Peters, J.D. (2002). Feminist metafiction and the evolution of the British novel. Gainesville: University Press of Florida.

Pleshakova, A. (2016). Meta-parody in contemporary Russian media: Viewpoint blending behind Dmitry Bykov's 2009 poem "Infectious". In Lege artis. Language yesterday, today, tomorrow. The journal of University of SS Cyril and Methodius in Trnava. Warsaw: De Gruyter Open, 2016, I (1), June 2016, p. 202-274. DOI: 10.1515/lart-2016-0005.

Pratchett, T. (2000). Equal rites. New York: Harper Collins.

Pratchett, T. (1996). Feet of clay. London: Gollancz. 
Pratchett, T. (2008). The illustrated wee free men. New York: Harper Collins.

Pratchett, T. (1992). Witches abroad. London: Corgi Books.

Prince, G. (1982). Narratology: The forms and functioning of narrative. Berlin-New York: Mouton Publishers.

Rose, M.A. (1979). Parody/meta-fiction: An analysis of parody as a critical mirror to the writing and reception of fiction. London: Taylor \& Francis.

Rowling, J.K. (2008). The tales of Beedle the Bard. London: Children's High Level Group.

Rushdie, S. (1991). Midnight's children. New York: Penguin Publishers.

Ryan, M.-L. (2006). Avatars of story. Minneapolis-London: University of Minnesota Press.

Ryan, M.-L. (2013). Impossible worlds and aesthetic illusion. In Immersion and distance. Aesthetic illusion in literature and other media. Wolf, W., Bernhart, W. \& Mahler, A. (eds.). Amsterdam-New York: Rodopi, p. 131-148.

Tolan, F. (2007). Margaret Atwood. Feminism and fiction. Amsterdam-New York: Rodopi.

Tykhomyrova, O.V. (2011). The fictional narrator game in "Nanny Ogg's cookbook". In Scientific papers: Scientific-methodological journal, 164 (Issue 152. Philology. Literary studies), p. 126-129. / Tykhomyrova O.V. Hra u fiktsijnoho avtora v "Kulinarnij knyzi Nanni Ogg". In Naukovi pratsi: Naukovo-metodychnyj zhurnal, 164 (Vypusk 152. Filolohiya. Literaturoznavstvo), s. 126-129. / Тихомирова О.В. Гра у фікційного автора в "Кулінарній книзі Нанні Огг". In Наукові пращі: Науковометодичний журнал, 164 (Випуск 152. Філологія. Літературознавство), с. 126129.

Tykhomyrova, O.V. (2011a). Metafictional narratives in the text and on the screen (a study of Ian McEwan's Atonement and its 2007 adaptation). In Scientific journal of the UNESCO Chair at the KNLU. Philology. Pedagogics. Psychology series, 22, p. 76-83. / Tykhomyrova O.V. Metafictional narratives in the text and on the screen (a study of Ian McEwan's Atonement and its 2007 adaptation). In Naukovyj visnyk kafedry YUNESKO KNLU. Seriya Filolohiya. Pedahohika. Psykholohiya, 22, s. 76-83. I 
Tykhomyrova O.V. Metafictional narratives in the text and on the screen (a study of Ian McEwan's Atonement and its 2007 adaptation). In Науковий вісник кафедри ЮНЕСКО КНЛУ. Серія Філологія. Педагогіка. Психологія, 22, с. 76-83.

Tykhomyrova, O.V. (2012). Polemics with Shakespeare in fantasy fiction. In Journal of Lviv university. Foreign languages series, 20 (2), p. 176-182. / Tykhomyrova O.V. Polemika z Shekspirom u literaturi fentezi. In Visnyk L'vivs'koho universytetu. Seriya Inozemni movy, 20 (2), s. 176-182. / Тихомирова О.В. Полеміка з Шекспіром у літературі фентезі. In Вісник Львівського університету. Серія Іноземні мови, 20 (2), c. 176-182.

Tykhomyrova, O.V. (2014). The "children's book" game as a narrative strategy in fantasy series. In Scientific papers: Scientific-methodological journal, 239 (Issue 227. Philology. Literary studies), p. 48-51. / Tykhomyrova O.V. Hra v "dytyachu knyhu" yak naratyvna stratehiya u fentezijnykh tsyklakh. In Naukovi pratsi: Naukovometodychnyj zhurnal, 239 (Vypusk 227. Filolohiya. Literaturoznavstvo), s. 48-51. I Тихомирова О.В. Гра в "дитячу книгу" як наративна стратегія у фентезійних циклах. In Наукові праџі: Науково-методичний журнал, 239 (Випуск 227. Філологія. Літературознавство), с. 48-51.

Waugh, P. (2001). Metafiction: The theory and practice of self-conscious fiction. New York: Routledge.

Williams, J. (2004). Theory and the novel. Narrative reflexivity in the British tradition. Cambridge: Cambridge University Press.

Wolf, W. (2005). Metalepsis as a transgeneric and transmedial phenomenon. A case study of the possibilities of 'exporting' narratological concepts. In Narratology beyond literary criticism. Mediality, disciplinarity. Meister J.C. (ed.). Berlin-New York: Walter de Gruyter, p. 83-107.

Wolf, W. (2013). Aesthetic illusion. In Immersion and distance. Aesthetic illusion in literature and other media. Wolf, W., Bernhart, W. \& Mahle, A. (eds.). AmsterdamNew York: Rodopi, p. 1-63.

Zelazny, R. (1978). The chronicles of Amber. Vol. I. New York: Nelson Doubleday. 


\begin{tabular}{|c|c|}
\hline $\begin{array}{l}\text { Contact data } \\
\text { Olena V. Tykhomyrova, } \\
\text { CSc. (Literary studies), } \\
\text { Associate professor at } \\
\text { Professor } \\
\text { Morokhovs'kyj } \quad \text { Depart- } \\
\text { ment of English Philology } \\
\text { and Philosophy of } \\
\text { Language, Kyiv National } \\
\text { Linguistic University, 73 } \\
\text { Velyka Vasyl'kivs'ka St., } \\
\text { Kyiv-150, CPS, } \\
\text { Ukraine; } \\
\text { olena.quest@gmail.com }\end{array}$ & \begin{tabular}{|l|} 
Fields of interest \\
Literary studies, narratology, \\
interdisciplinary studies of \\
fantasy fiction, stylistics, \\
multimodality studies.
\end{tabular} \\
\hline
\end{tabular}

\section{Résumé}

This paper focuses on metafictional narrative strategies characteristic of contemporary English-language fiction. The aim of the research is to outline different forms of textual self-reflexivity and liminality, to determine their narrative manifestations, and to uncover their stylistic potential. The theoretical assumptions of the paper are drawn from the bulk of research done on the subject of metafiction and aesthetic illusion, including works by Fludernik, Hanebeck, Hutcheon, Rose, Ryan, Waugh, Wolf, Williams, and others. Methodologically, narrative theories are employed, while the state of aesthetic illusion is considered in terms of immersion and distance. Various effects produced in metafictional narratives are analyzed with regard to linguistic foregrounding. The paper addresses transgressions between narratives levels, defining the scope and ontological status of narrative metalepsis. Specific framing arrangements and plot structures are viewed with regard to their self-reflexivity. Numerous examples of metafictional commentary are provided to throw light on different levels at which this strategy can function in the text. Metafictional parody and pastiche are shown to have a revisionist potential, as they critically juxtapose narrative patterns characteristic of different genres and cultural eras. The paper also considers metaphors relating to the acts of reading / writing fiction and the participants of these processes. The stylistic effects, among which the most prominent are irony and ambiguity, have been 
elucidated. The paradoxical effect of authentication, resulting in an engaging storyworld, has been described as particularly resonant for fantasy fiction. The analysis has demonstrated that sophisticated narrative games based on the transgression between narrative levels foreground the act of book-creation and enhance the effect of interconnectivity between the fictional and the real worlds. On the whole, metafictional sensitivity, permeating numerous contemporary texts, advertises fiction and narrativization itself as essential for the human condition and ultimately desirable in terms of its cognitive impact.

Key words: fantasy fiction, fictionality, genre, illusion, liminality, magic realism, metafiction, metalepsis, metaphor, narrative strategy, paradox, parody, plot, selfreflexivity.

Article was received by the editorial board 14.01.18;

Reviewed 06.02.18. and 11.03.18.

Similarity Index 8\% 